\title{
A Comparative Study of Modern Theatrical Technicalities in The Glass Menagerie and The Cherry Orchard
}

\section{Shokhan Rasool Ahmed}

English Department, College of Languages, University of Sulaimani, Sulaimani, Kurdistan Region, Iraq.

E-mail: shokhan.ahmed@univsul.edu.iq

\section{Abstract:}

The nineteenth Century produced some of the most complex plays that today represent modern theatrical technicalities that differed in several ways from twentieth Century plays. In the twentieth Century, Tennessee Williams was acknowledged for the diversity of genres he covered in his plays, most of which focused on the dark aspects of human experience, which lent significant technicalities to his plays, most notably, The Glass Menagerie. Similarly, Anton Chekhov is a nineteenth Century playwright who developed plays that introduced several theatrical technicalities. He was renowned for portraying realism, a feature that characterised $19^{\text {th }}$ Century theatre. Chekhov's The Cherry Orchard is a play considered the landmark of modern theatrical technicalities.

This study explores three ways in which Williams and Chekhov made The Glass Menagerie and Cherry Orchard respectively as landmarks of theatrical technicalities, i.e., the multiplicity of genres, effective use of indirect action and irony as theatrical conventions, and the integration and portrayal of nineteenth Century and twentieth Century realism. The research finds that while Williams employs a multiplicity of genres and the use of irony as the ideal theatrical conventions, Chekhov integrates all three elements to create modern theatrical technicalities that not only influence the audience's perception of the characters but also the playwright's intention.

This study is important for both undergraduate and postgraduate readers as it can enrich a reader's thinking about different theatrical techniques and conventions used in both plays.

Keywords: The Glass Menagerie, The Cherry Orchard, Realism, and Theatrical Technicalities. 


\section{Introduction:}

$19^{\text {th }}$ Century theatre play had a significant impact on the development of the theatre in Europe as well as $20^{\text {th }}$ Century theatre. While several playwrights had a significant influence on $19^{\text {th }}$ Century Theatre, Anton Chekhov had a tremendous impact on theatre while Tennessee Williams had a significant impact on $20^{\text {th }}$ Century theatre. While Chekhov was renowned for portraying realism, a feature that characterised $19^{\text {th }}$ Century Theatre, Williams was often compared with the writers of narrative fiction for his contrasting approach. Both Williams and Chekhov effectively employ theatrical technicalities and theatrical conventions to make The Glass Menageries and The Cherry Orchard landmarks of modern theatrical technicalities, but they differ in their approach to realism. Bonyadi (2012) argues that the theatrical technicalities in the Cherry Orchard are evidenced by the complexity of the characters Chekhov employs. The heroes in The Cherry Orchard come from different social classes and Chekhov employs sharp satire to keep the audience attentive to the complex political and social situations that define $19^{\text {th }}$ Century Russia (Bonyadi, 2012). Similarly, The Glass Menagerie depicts similar and significant elements that accentuate the complexity of human experience. Young (2007) argues that The Cherry Orchard is characterised by detailed, cluttered, and naturalistic settings, which contribute to the theatrical technicalities of the play. This paper argues that both The Glass Menagerie and The Cherry Orchard are landmarks of technical difficulties but they differ in the realistic approach Chekhov employs compared to William's nonrealistic approach.

\section{I. "The Glass Menagerie" and "The Cherry Orchard" as an Exemplum of Modern Theatrical Technicalities}

The Glass Menagerie and The Cherry Orchard can be perceived as an exemplum of modern theatrical technicalities because of several elements of William's and Chekhov's styles that distinguish their works. One of the outstanding features of William's The Glass Menagerie and Chekhov's The Cherry Orchard is the contrivance that allowed for the existence of numerous themes that transcended the conventional classification of plays into genres.

In The Glass Menagerie, Tennessee Williams employs a variety of themes that makes the play a blend of different genres. The Glass Menagerie fits the classification of 1) memory play 2) tragedy), 3) comedy, and 4) drama. Williams is credited with the first memory play when he published The Glass Menagerie. The entire play, including the description and characterization of the other characters, is based on the narrator's recollection of the events in his past. At the end of Scene vii, Tom, the narrator says, 
"I left Saint Louis. I descended the steps of this fire escape for the last time and followed, from then on, in my father's footsteps, attempting to find in motion what was lost in space" (Williams \& Walker, 2019)

This excerpt is an indicator that the entire play is based on his recollection of the events in his past. Employing this format allowed Williams the freedom to portray the characters in a biased manner that is influenced by the narrator's emotion as well as the temporal distance. The use of a memory play allows for the exaggeration of specific characteristics, such as Laura's characterization as an extremely shy girl. The outstanding feature of the play is the tragedy that seems to constantly pursue the narrator's family. Not only is the family abandoned by the head of the household but they also face individual emotional struggles that affect their ability to remain a cohesive family.

"When people have some slight disadvantage like that, they cultivate other things to male up for it - develop charm - and vivacity - and - charm! That's all you have to do!" [She turns again to the photograph]. "One thing your father always had plenty of - was a charm!" (Williams \& Walker, 2019).

This excerpt depicts the circumstantial detail that despite the anguish that Amanda experienced from being abandoned by her husband, she still had hope for a better outcome for her daughter Laura. She is affected emotionally by suffering abandonment and is tormented similar fears for her daughter but holds out hope for better outcomes (Guan, et al., 2016). It is tragic that Jim, the one person recommended by Tom and liked by Laura, is engaged. It is also tragic that despite his awareness of the effects of abandonment, Tom chooses to leave his sister and mother without any form of support.

While the play can be perceived as a tragedy similar to The Cherry Orchard, changing the character in focus reveals the humour beneath the tragedy. Focus on Amanda reveals humour in her actions and behaviour. Despite the hardship she has experienced as a single mother, she still holds on to the sugar-coated memories as a Southern belle.

"All of my gentlemen callers were sons of planters and so of course I assumed that I would be married to one and raise my family on a large piece of the lad with plenty of servants. But man proposes - and the woman accepts the proposal! To vary that old, old saying a little bit — I married no planter! I married a man who worked for a telephone company! That gallantly smiling man over there! A telephone man who-fell in love with long-distance! Now he travels and I don't even know where!" (Williams \& Walker, 2019) 
She is stuck in her past as she constantly reminisces about her past suitors as well as her husband. She is obsessed with her husband and her past life despite the pain it has caused her (Eliott, 2013). This is evidenced when she vivaciously chats with Jim as Laura hid in her room.

[coyly smiling, shaking her girlish ringlets]: Well, well, well, so this is Mr. O'Connor. Introductions are entirely unnecessary. I've heard so much about you from my boy. I finally said to him, Tom — good gracious! — why don't you bring this paragon to supper? (Williams \& Walker, 2019)

This excerpt depicts that Amanda dressed as a young Southern belle. She immediately begins to chat with Jim, Additionally, the arguments between Amanda and Tom, especially the ones over getting a suitor for Laura portray the comedy in the play (Eliott, 2013). Williams does not separate the humour from the tragedy as is customary for dramatic works. Like Chekhov, Williams blurs the boundaries between these two genres. While Williams perceived The Glass Menagerie as a tragic memory play, it has often been classified and performed as a comedy. Despite the sadness that characterises The Glass Menagerie, the comic elements are intertwined with the elements perceived as tragic.

Like William's, Chekhov employed a variety of themes that leads to The Cherry Orchard fitting several genre classifications. The Cherry Orchard has been classified as a 1) comedy 2) tragedy, or 3) drama. Dramatic works have conventionally distinguished between humour and tragedy, keeping them separate. While this strategy has been widely employed to achieve specific playwright goals and objectives, Chekhov blurs the boundaries between these two genres. Chekhov is innovative in his work that it is difficult to distinguish The Cherry Orchard as either a tragedy or humour (Dykes, 2016). While Chekhov perceived The Cherry Orchard as a comedy, it has often been classified and performed as a tragedy. According to Chekhov, despite the sadness that characterises The Cherry Orchard, the comic elements should pervade the elements perceived as tragic. The standout aspects of the plot indicate that The Cherry Orchard is a tragedy. This is evidenced by an aristocrat losing all their wealth and slipping into bankruptcy.

Play on, music! [The band plays. LUBOV ANDREYEVNA sinks into a chair and weeps bitterly. LOPAKHIN continues reproachfully] Why then, why didn't you take my advice? My poor, dear woman, you can't go back now. [Weeps] Oh, if only the whole thing was done with if only our uneven, unhappy life were changed!

Madame Ranevsky, an aristocrat accustomed to a lavish lifestyle, acknowledges the loss of her beloved cherry orchard. This excerpt qualifies The Cherry Orchard as a tragedy (Chen, 2019). Despite portraying the growth of Lophakin from being a surf to a master, it shows the decline of a dynasty that had existed for generations. 
However, The Cherry Orchard can be perceived as a comedy when the audience chooses to focus on Lopakhin. In the Cherry Orchard, Lopakhin is the only character with the courage to overcome their circumstances to achieve his ambition (Latham, 1958). He is perceived as the hero of The Cherry Orchard because of his ability to overcome tragedy to obtain a happy ending.

\section{Theatrical Conventions in "The Glass Menagerie" and "The Cherry Orchard"}

Second, Williams's The Glass Menagerie and Chekhov's The Cherry Orchard can be perceived as an exemplum of modern theatrical technicalities because of their use of theatrical conventions that make both works unique plays. While Williams and Chekhov employed several theatrical conventions, two theatrical conventions, i.e., a) indirect action, and b) irony played a vital role in making The Cherry Orchard, and irony in making The Glass Menagerie epitomes of modern theatrical technicalities.

\section{A. Indirect Action}

One of the outstanding differences in the theatrical conventions employed by Williams in The Glass Menagerie and Chekhov in The Cherry Orchard is Indirect action. Indirect action entails action that is critical or central to a play's plot taking place off-stage as opposed to on stage (Abidi, 2013). Chekhov's use of this strategy has a significant impact on the audience in The Cherry Orchard. The audience does not learn about these actions except through the reactions of the actors on stage. However, Williams does not employ this strategy, a fact that is attributed to his non-realistic approach.

In Act III, Chekhov employs indirect action to allude to the sale, which is integral to the plot.

LOPAKHIN: "[Confused, afraid to show his pleasure] The sale ended up at four o'clock... We missed the train and had to wait till half-past nine. [Sighs heavily] Ooh! My head's going round a little."

In this excerpt from Act III, Lopakhin narrates the sale of the cherry orchard, which is an integral event to the plot. Despite the fact of its significance, the event does not take place on stage. The audience only learns about the auction through the reactions of actors on stage. The use of indirect action by Chekhov at the end of Act III highlights and accentuates the theme of personal desire which differs for each of the characters (Griffin, 2007). It highlights Lopakhin's thirst for power, which he achieves by winning the auction of the cherry orchard. As such, in Act III, Chekhov's use of indirect action allows him to position the characters against each other. The indirect action of Lopakhin purchasing the cherry orchard pits him against Madame Ranevsky. Apart from pitting the characters against each other, Chekhov uses indirect action in Act III to depict the social and cultural changes at the time, i.e., the liberation of serfs in Russia during the $19^{\text {th }}$ Century (Evdokimova, 2000). 
Similarly, Chekhov uses indirect action in Act I, when Anya criticises the spendthrift behaviour of her mother, Madame Ranevsky when she was in France.

"She's already sold her villa near Mentone; she's nothing left, nothing. And I haven't a copeck left either; we only just managed to get here, and mother won't understand! We had dinner at a station; she asked for all the expensive things and tipped the waiters one rouble each. And Charlotta too. Yasha wants his share too-- it's too bad. Mother's got a footman now, Yasha; we've brought him here."

The audience are unable to witness themselves Madame Ravensky's extravagance; but, their off-stage spending significantly influences the reactions of Anya and significantly drives the plot. Anya's reaction informs the audience of the plausible reasons for Ranevsky's financial woes (Chen, 2019). Her spendthrift actions, though not evident on stage, play a significant role in developing and enhancing the dramatic intensity of the plot. The audience is provided with more information about Madame Ranevsky's personality. In this excerpt, Chekhov employs indirect action to show the complexity of Madame Ranevsky's character. She is portrayed as an individual who is not only driven by passion

In the same act, Lopakhim's opening speech highlights Chekhov's use of indirect action. In this speech, Lopakhim provides the audience with more background information, which plays a vital role in influencing the development of the action of the characters on stage.

I remember when I was a boy of fifteen, my father, who is dead--he used to keep a shop in the village here--hit me on the face with his fist, and my nose bled...My father was a peasant, it's true, but here I am in a white waistcoat and yellow shoes . . . a pearl out of an oyster. I'm rich now, with lots of money, but just think about it and examine me, and you'll find I'm still a peasant down to the marrow of my bones. [Turns over the pages of his book] Here I've been reading this book, but I understood nothing. I read and fell asleep. [Pause.]

Even though the events detailed by Lopakhim do not take place on stage, they have a significant impact on the plot of the story. They do not only highlight Lopakhim's position but also provide the audience with the first glimpse of his nature that is driven by the thirst for power.

By and large, Chekhov effectively uses indirect action to create and enhance dramatic intensity: the reaction of the characters onstage to the sale of the cherry orchards enhances the dramatic intensity of the role reversal that has taken place. It accentuates the dramatic intensity of Lopakhim, a serf, becoming the master, while the initial master, Madame Ranevsky, becomes homeless. 


\section{B. Irony}

Williams employs and integrates irony in The Glass Menagerie in a complex manner that enhances themes throughout the play. Williams employs irony to highlight the theme of blindness. This is especially evident in the relationship between Tom and his mother, Amanda. When Amanda argues with Tom,

"But I get up. I go! For sixty-five dollars a month I give up all that I dream of doing and being ever!" (Williams \& Walker, 2019)

In this excerpt, elements of irony are intertwined with the theme of blindness. It is ironic that despite Tom sacrificing his freedom, dreams, and desires to cater to the needs of the family, Amanda accuses him of selfishness. Amanda is blind to the fact that Tom could decide to abandon them as her husband. She is blind to the impact Tom's sacrifices have on his happiness.

Likewise, Chekhov employs irony in a complex way that not only helps achieve the comical effect but also enhances specific themes in the play, especially blindness (Young, 2007). A standout uses of irony with the theme of blindness by Chekhov is in the perceptions of Lopakhin, Dunyasha, and Firs. Even though they face different circumstances, they praise a system that supposedly allows for economic mobility (Young, 2007). However, the irony lies in the fact that they are blind to the factors that impede others around them who have no prospects to realise economic mobility (Griffin, 2007). They are blinded to the fact that systemic factors impeded the social and economic mobility of the marginalised in their society.

Chekhov also employs irony to highlight the complexity of the characters (Loehlin, 2006). As mentioned, Madame Ranevsky is a complex character that depicts different conflicting aspects of her personality. Chekhov employs irony in Act II to reveal the complex nature of Madame Ranevsky's personality.

"LUBOV: I had a lot of money yesterday, but there's very little today. My poor Varya feeds everybody on milk soup to save money, in the kitchen the old people only get peas, and I spend recklessly. [Drops the purse, scattering gold coins] There, they are all over the place.

YASHA. Permit me to pick them up. [Collects the coins.]

LUBOV. Please do, Yasha.”

In this excerpt, Madame Ranevsky laments her inability to control her finances, especially due to her spendthrift habits. Despite this self-aspersion, her actions contradict her lamentation (Evdokimova, 2000). Yasha is established as a character that is untrustworthy in The Cherry Orchard. Ranevsky is innately aware of Yasha's untrustworthy personality and still allows her to pick up her purse that has spilled its contents, including valuables (Storm, 2011). Even though 
she laments her ineptitude in personal financial management, she neglects to consider the safety of her valuables when dealing with Yasha. In this scene, Chekhov employs irony to highlight Madame Ranevsky's blindness to her financial problem. She only acknowledges the general financial weakness but is oblivious to her general ineptitude in financial matters. It highlights the complex intersection between irony and the theme of blindness in The Cherry Orchard.

\section{III. "The Glass Menagerie" as an Epitome of $2^{\text {th }}$ Century Non-realism and "The Cherry Orchard" as an Epitome of $19^{\text {th }}$ Century Realism}

The Glass Menagerie takes a contrasting approach as Williams adopts a non-realistic approach. This strategy was intentionally adopted by Williams because he did not perceive realism as an ideal approach to portraying human emotion. As a $20^{\text {th }}$ Century playwright, Williams adopts distortion, symbolism, and myth to develop an expressionistic portrayal of human emotion. This is evidenced by the fact the narrator's memory serves as the basis of the story. As such, the play is characterized by Tom's sentimentality and lacks foundational elements of realism.

The Cherry Orchard also epitomises the realism that characterised $19^{\text {th }}$ Century arts in Europe. In the $19^{\text {th }}$ Century, arts depicted contemporary life in its accurate and unembellished form. Chekhov's The Cherry Orchard epitomises $19^{\text {th }}$ Century realism through its characterisation and depiction of society. As mentioned, Chekhov employs indirect action to portray the social and cultural changes at the time, i.e., the liberation of serfs in Russia during the $19^{\text {th }}$ Century (Evdokimova, 2000). As such, The Cherry Orchard portrays social realism through the liberation of Lopakhim and his eventual victory through the acquisition of the cherry orchard. Despite Checkhov selecting the specific elements of the liberation of the surfs to integrate into the play, he portrays the complexity of the characters in a manner that the audience does not get to over sympathise with one character.

A salient example of realism is Lopakhin's boastfulness of his victory by purchasing the orchard. He portrays his true nature and his hidden feelings and thoughts of those born into wealth.

LOPAKHIN. I bought it! Wait, ladies and gentlemen, please, my head's going around, I can't talk... [Laughs]

He not only boasts his victory by acquiring the cherry orchard, he also rubs it in by bragging about how he won the auction.

LOPAKHIN. Leonid Andreyevich had only fifteen thousand roubles, and Deriganov offered thirty thousand on top of the mortgage, to begin with. I saw how matters were, so I grabbed hold 
of him and bid forty. He went up to forty-five, I offered fifty-five. That means he went up by fives and I went up by tens... Well, it came to an end. I bid ninety more than the mortgage, and it stayed with me. The cherry orchard is mine now, mine! [Roars with laughter] My God, my God, the cherry orchard's mine! Tell me I'm drunk, or mad, or dreaming.

While the audience is tempted to sympathise with Lopakhin because of his peasant background, the brutality of his boastfulness is a betrayal of those roots and depicts the duplicity of the serf's liberation (Beckerman, 1971). While the liberation of the surfs in the $19^{\text {th }}$ Century was perceived as the triumph of democracy and the demolition of the establishment, it was also marked with bitterness for years of subjugation and marginalisation. This is portrayed in the way Lopakhin boastfully informs the former masters of his plans to destroy their cherished cherry orchard.

LOPAKHIN. Eh, musicians, play, I want to hear from you! Come and look at Ermolai Lopakhin laying his axe to the cherry orchard, come and look at the trees falling! We'll build villas here, and our grandsons and great-grandsons will see a new life here... Play on, music! [The band plays. LUBOV ANDREYEVNA sinks into a chair and weeps bitterly. LOPAKHIN continues reproachfully]

Despite his humble origins, the bitterness associated with generations of subjugation and suffering at the hands of masters drives Lopakhin to take joy and pleasure in destroying the very notion of the cherry orchard. He not only seeks to gain power but to destroy every symbol of the power of the former masters by boasting of his intention to cut down the cherry orchard. The Cherry Orchard through the character of Lopakhin portrays the wishes and aspirations of the working class in $19^{\text {th }}$ Century Russia.

Chekhov's integration of $19^{\text {th }}$ Century realism has a significant impact on the audience's perceptions of the characters and the subject matter. It has a significant impact on the audience by allowing them to perceive Chekhov's objectivity in portraying Russian society (Young, 2007). The audience not only gets to acknowledge the validity of the liberation of the surfs as portrayed by Lopakhin but they also acknowledge the ruthlessness of the liberation. As such, it portrays the liberation of surfs as a double-edged sword, which epitomises The Cherry Orchard as a portrayal of $19^{\text {th }}$ Century realism.

\section{Conclusion}

Williams and Chekhov effectively leverage literary strategies to develop The Cherry Orchard as landmarks of modern theatrical technicalities. The heroes in The Cherry Orchard come from different social classes. Chekhov employs sharp satire to keep the audience attentive to the complex political and social situations that define $19^{\text {th }}$ Century Russia (Bonyadi, 2012). The 
contrivance allowed for the existence of numerous themes that transcended the conventional classification of plays into genres.

In the Glass Menagerie, Tennessee Williams employs a variety of themes that make the play a blend of assorted genres. Williams avoids separating humour from the tragedy as is customary for dramatic works. Williams blurs the boundaries between these two genres. Employing a memory play format allowed Williams the freedom to portray the characters in a biased manner that is influenced by the narrator's emotion as well as the temporal distance. The use of a memory play allows for the exaggeration of specific characteristics. While the play can be perceived as a tragedy similar to The Cherry Orchard, changing the character in focus reveals the humour beneath the tragedy. Focus on Amanda reveals humour in her actions and behaviour. Similar to Williams, Chekhov blurs the boundaries between comedy and tragedy. The standout aspects of the plot indicate that The Cherry Orchard is a tragedy. However, The Cherry Orchard can be perceived as a comedy when the audience chooses to focus on Lopakhin. Similarly,

Williams's and Chekhov's use of theatrical conventions makes their works unique plays. Chekhov's use of indirect action allows him to position the characters against each other in contrast to William's non-realistic style that is not suited to this approach. Chekhov uses indirect action to depict the social and cultural changes at the time. Chekhov employs indirect action to show the complexity of characters. Chekhov effectively uses indirect action to create and enhance dramatic intensity.

Both Williams and Chekhov employ irony in a complex way that not only helps them achieve the comical effect but also enhances specific themes in the play, especially blindness. It highlights the complex intersection between irony and the theme of blindness in The Glass Menagerie and The Cherry Orchard. Williams employs and integrates irony in The Glass Menagerie in a complex manner that enhances themes throughout the play. Similar to Chekhov, Williams employs irony to highlight the theme of blindness. While Chekhov epitomizes $19^{\text {th }}$ Century realism, William's The Glass Menagerie takes a contrasting approach as Williams adopts a non-realistic approach.

The Cherry Orchard epitomises $19^{\text {th }}$ Century realism through its characterisation and depiction of society. Despite Chekhov's selecting the specific elements of the liberation of the surfs to integrate into the play, he portrays the complexity of the characters in a manner that the audience is skilfully protected against exaggerated sympathy with one or more characters. On the other hand, Williams' non-realistic approach relies on the biased influence of the narrator. 


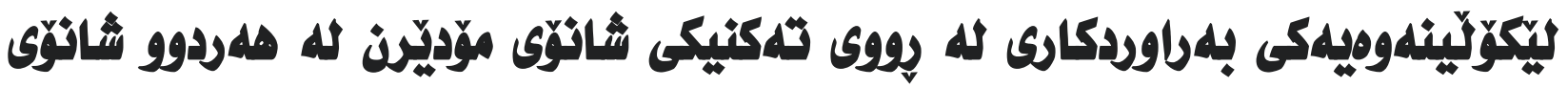 The Glass Menagerie g The Cherry Orchard
}

\author{
شوَخان رِمسولْ احمد
}

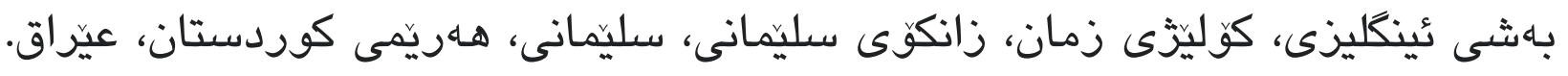
shokhan.ahmed@univsul.edu.iq :يمهيل'

צوخته:

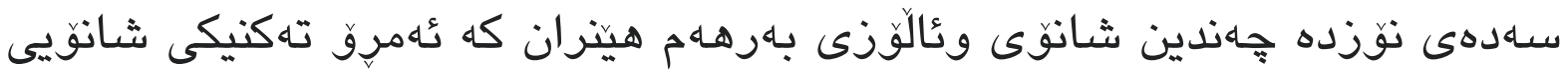

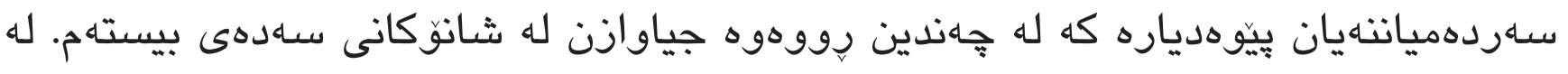

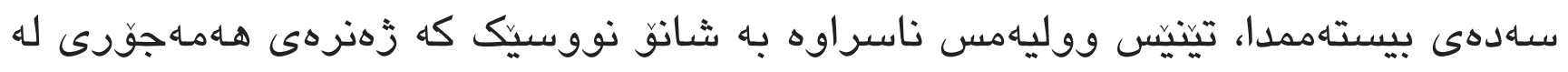

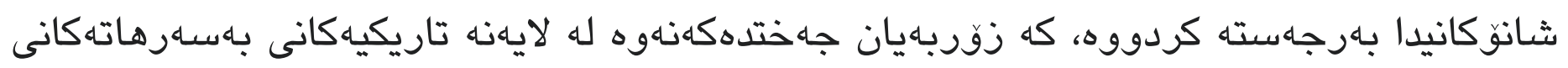

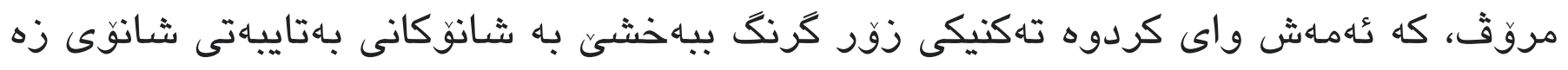

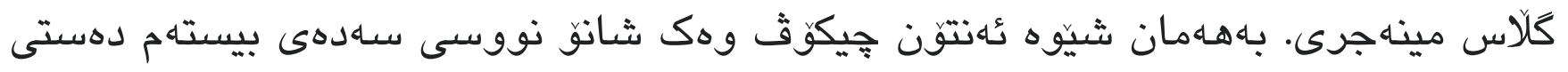

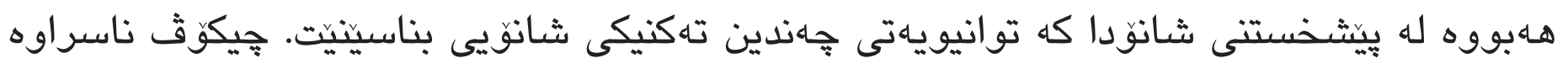

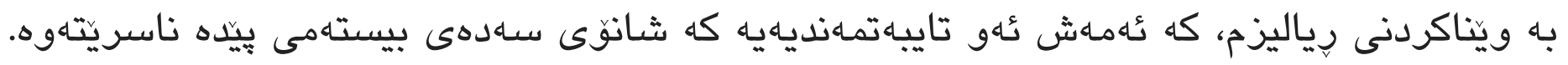

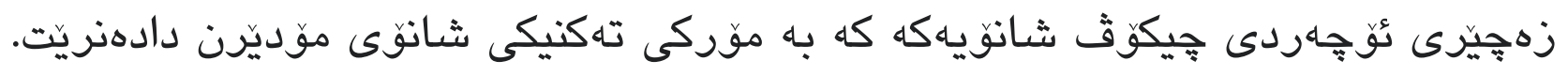

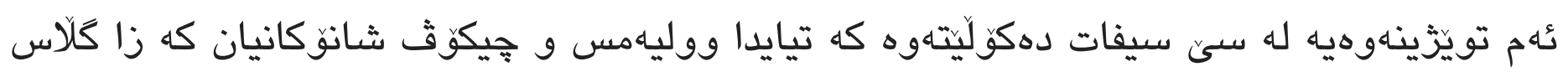

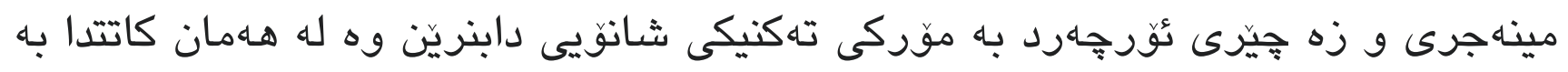

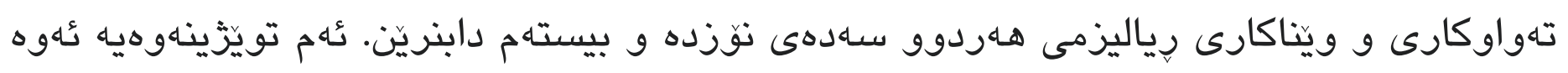

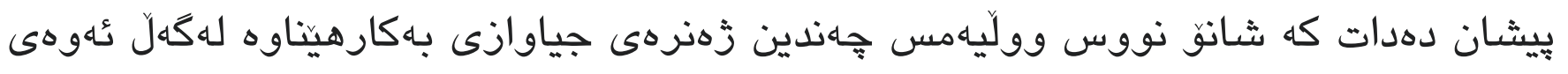

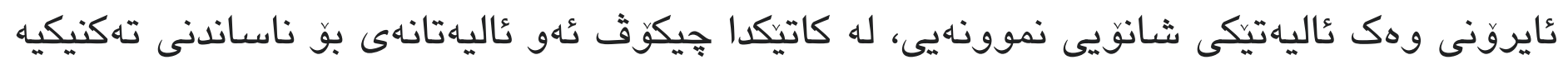




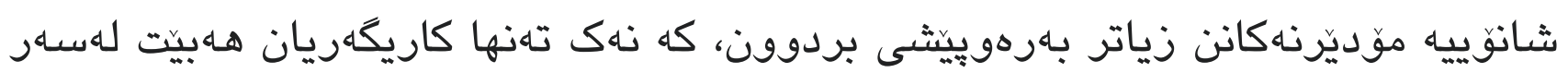

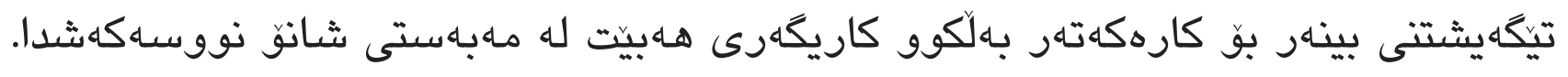

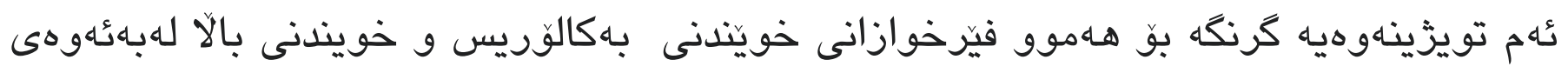

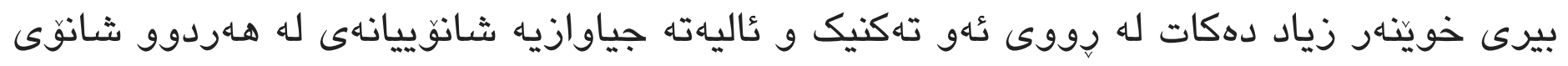
ناوبراودا بهرجهاسته كراون.

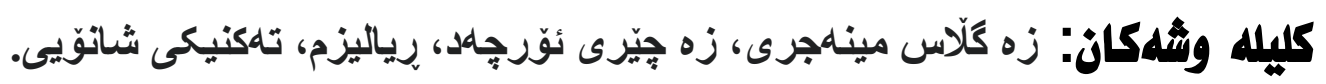




\section{Bibliography:}

Abidi, S. A., (2013). Mulitiplicity of meanings in Chekhov's The Cherry Orchard. Lapis Lazuli -An International Literary Journal (LLILJ), 3(1).

Beckerman, B., (1971). Dramatic analysis and literary interpretation: The cherry orchard as exemplum. New Literary History, 2(3), pp. 391-406.

Bonyadi, A. R., (2012). Previous, Present and Future Characters in 'Cherry Orchard'Play. Journal of American Science, 8(3), pp. 9-14.

Chen, Y., (2019). Time and Memory in The Cherry Orchard. Journal of Language Teaching and Research, 10(5).

Dykes, S., (2016). STRANGE FRUIT, Chekhov's The Cherry Orchard in the Deep South. Stanislavski Studies, 4(2), pp. 185-203.

Eliott, K., (2013). The Glass Menagerie by Tennessee Williams (review). Educational Theatre Journal, 65(4), pp. 584-585.

Evdokimova, S., (2000). What's so Funny about Losing One's Estate, or Infantilism in “The Cherry Orchard". The Slavic and East European Journal, 44(4), pp. 623-648.

Griffin, B., 2007. The Cherry Orchard. Theatre Journal, 59(1), pp. 127-129.

Guan, Y., Jia, L. \& Gao, Y., (2016). Fragile as Escaping into the Glass World-Analysis of The Glass Menagerie from the Perspective of Cognitive Domains. Advances in Literary Study, 4(4), pp. 67-76.

Latham, J. E., (1958). The Cherry Orchard as Comedy. Educational Theatre Journal, 10(1), pp. 21-29.

Loehlin, J. N., (2006). Chekhov: The Cherry Orchard. s.l.:Cambridge University Press.

Storm, W., (2011). Irony and the Modern Theatre. s.l.:Cambridge University Press.

Williams, T. \& Walker, K., (2019). The Glass Menagerie. s.1.:New Directions.

Young, S., (2007). A Blind Spot: Chekhov's Deepest Horizons. Journal of Dramatic Theory and Criticism, 21(1), pp. 65-78. 